\title{
Considerations on the role of environmental toxins in idiopathic Parkinson's disease pathophysiology
}

\author{
Francisco Pan-Montojo ${ }^{1,2^{*}}$ and Heinz Reichmann ${ }^{3}$
}

\begin{abstract}
Neurodegenerative diseases are characterized by a progressive dysfunction of the nervous system. Often associated with atrophy of the affected central or peripheral nervous structures, they include diseases such as Parkinson's Disease (PD), Alzheimer's Disease and other dementias, Genetic Brain Disorders, Amyotrophic Lateral Sclerosis (ALS or Lou Gehrig's Disease), Huntington's Disease, Prion Diseases, and others. The prevalence of neurodegenerative diseases has increased over the last years. This has had a major impact both on patients and their families and has exponentially increased the medical bill by hundreds of billions of Euros. Therefore, understanding the role of environmental and genetic factors in the pathogenesis of PD is crucial to develop preventive strategies. While some authors believe that PD is mainly genetic and that the aging of the society is the principal cause for this increase, different studies suggest that PD may be due to an increased exposure to environmental toxins. In this article we review epidemiological, sociological and experimental studies to determine which hypothesis is more plausible. Our conclusion is that, at least in idiopathic PD (iPD), the exposure to toxic environmental substances could play an important role in its aetiology.
\end{abstract}

Keywords: Idiopathic Parkinson's disease, Environmental toxins, Gene-environment interactions, Braak's staging and pathology progression

\section{Introduction}

PD affects around $1 \%$ of the general population a rate that increases with age reaching up to $5 \%$ of the 80 years old population [1]. Its annual incidence is between 16 and 19 per 100,000 per year [2]. It affects all races equally, with slight male predomination. In Europe PD prevalence is 1,6/ 100 inhabitants, with a wide variability between different countries [3]. Although multiple genetic forms of the disease have been observed [4], they account for less than $10-15 \%$ of the total cases and their importance vary between different regions [5]. If iatrogenic and vascular parkinsonisms are included together with complex degenerative diseases and atypical parkinsonisms, the total prevalence increases to 2,3/100. During the twentieth

\footnotetext{
* Correspondence: francisco.pan-montojo@med.uni-muenchen.de

${ }^{1}$ Neurologische Klinik, Klinikum der Ludwig-Maximilians-Universität München, Marchioninistr. 15, 81377 Munich, Germany

${ }^{2}$ Munich Cluster for Systems Neurology (SyNergy), Adolf-Butenandt-Institut Ludwig-Maximilians-Universität München, Schillerstr. 44, 80336 Munich, Germany

Full list of author information is available at the end of the article
}

century, the general incidence of PD increased 1.63 times. This increase occurred mostly during the first half until 1980 and affected developed countries [6,7]. Similarly, other neurodegenerative diseases have dramatically increased in some regions and decreased in others [8]. Interestingly, this increase is most evident in developed countries and within these countries in those regions using agrochemical compounds [9-11]. Some studies claim that such an increase is due to the aging of the population, associated with mitochondrial dysfunction and a reduced protective response to oxidative stress, other studies point to the interaction between environmental toxins and diverse genetic backgrounds as the main triggers of PD. In this work, we show evidence supporting these two different hypotheses in relation with the most recent findings on PD pathophysiology with special emphasis on iPD. 


\section{A historic perspective on Parkinson's disease and its relation with toxic and protective environmental substances}

The English physician James Parkinson in his work "An essay on the Shaking Palsy" described PD for the first time in 1817. This correlates well with the beginning of the industrial and chemical revolution in Europe during the late $18^{\text {th }}$ century and the $19^{\text {th }}$ century. To our knowledge, only the Ayuverda (the medical system practiced in India around 5000 years before Christ) and the first Chinese manuscript on medicine, Nei Ping, written 2500 years ago, describe some of the symptoms observed in PD and potential treatments [12,13]. Apart from this reference to PD-related symptoms, no other physician in any of the occidental countries had previously described the complex amalgam of symptoms typical of this disorder. This suggests that either these different symptoms had always been misdiagnosed as separate entities throughout history, not recognized as part of a syndrome, or the prevalence of PD until the beginning of the $19^{\text {th }}$ century had been extremely low. While possible, the first hypothesis seems quite improbable to us. Many PD symptoms are quite striking and would have been described and published before Parkinson's assay. Therefore, we believe that a dramatic increase of PD cases occurred in parallel to the industrial revolution. In this case, the question is, why?

Some authors have related the increase of PD incidence to the aging of the population $[14,15]$. Aging has been associated to the impairment of the antioxidant body system and mitochondrial function [16]. It is known that age-related non-genetic PD appears between the $5^{\text {th }}$ and $6^{\text {th }}$ decade of life. Logically, an increase in life expectancy would lead to an increased incidence and prevalence of PD. However, in the last 1000 years life expectancy at 15 years of age (i.e. discounting birth and child mortality) has always been above these values $[17,18]$. Interestingly, a general increase in PD incidence was observed during the first half of the twentieth century from 11,4/100.000 inhabitants between 1935 and 1944 to 18,2/100.000 inhabitants in both young and old populations between 1967 and 1979 [6,7]. Since then it has remained more or less constant due to a compensation effect. There has been a decrease in the incidence rate in the population under 69 years of age and an increase in the population over 70 years [6]. Altogether, these data suggests that the increase in PD incidence cannot be due to the aging of the population alone.

Accordingly, the appearance of iPD has been related to industrial and rural environments due to the higher exposure to environmental toxins $[10,19]$. Natural pesticides have been used since more than 5000 thousand years. The first known pesticide was elemental sulfur dusting used about 4,500 years ago. Also, the Rig Veda, which is about 4,000 years old, mentions the use of poisonous plants for pest control [20]. However, it was not until the 15th century that toxic chemicals such as arsenic, mercury, and lead were applied to crops to kill pests. Later, nicotine sulfate was extracted from tobacco leaves for use as an insecticide in the 17th century. Remarkably, only in the 19th century two pesticides related to $\mathrm{PD}$, pyrethrum, derived from chrysanthemums, and rotenone, which is derived from the roots of tropical vegetables, started to be used [21].

Other more recent epidemiological studies have broadened the link between PD and other environmental factors including drinking well water, rural living, farming, diet and exposure to agricultural chemicals [22-24]. The environmental contribution to PD's pathophysiology has been also analysed. Farm and industrial compounds seem to increase the risk of Parkinsonism [11,22,25-28]. Farm activity is associated with agriculture and exposure to pesticides [24]. Organochlored pesticides were identified as a risk factor in a German case-control study [27] and another study with similar conclusions was conducted with dithiocarbamates [28]. Levels of organochlorines have been found to be elevated in the brains of persons with iPD [29]. A study of French elderly individuals found an association between past occupational exposures to pesticides, low cognitive performance, and increased risk of developing Alzheimer's disease or iPD [9]. In a more recent epidemiological study, Tanner and colleagues have tried to identify a common characteristic of those pesticides that present a higher correlation to the appearance of PD [30]. They conclude that pesticides inhibiting the mitochondrial Complex I and increasing oxidative stress are more prone to induce iPD upon exposure. Together with pesticides and herbicides it has been observed that some xenobiotics like annonacin induce Parkinsonian symptoms in humans and a loss of nigrostriatal neurons in animals [31].

iPD has also been linked to the exposure to different metals and industrial compounds. Many studies performed in the 90's identified manganese, lead, copper, iron, zinc, aluminium or amalgam (reviewed in [24]). Higher incidence of iPD has been reported in manganese miners [32]. It was shown that manganese, a component of various pesticides, also reproduces parkinsonian symptoms after long and chronic exposures (between 6 months and 16 years). Also, concern was raised that widespread introduction of the manganese-containing fuel additive methylcyclopentadienyl manganese tricarbonyl to the U.S. gasoline supply may increase population exposure to manganese and thus increase risk of parkinsonism in sensitive populations [33]. A more recent study has also shown a positive correlation between $ß$-Hexachlorocyclohexane blood levels and iPD [34].

The positive relation between exposure to environmental toxins and neurodegenerative diseases is not 
limited to PD. For example, the Chamorros population of Guam and Rota in the western Pacific has an unusually high prevalence of motor neuron disease, a syndrome that includes amyotrophic lateral sclerosis, parkinsonism, and progressive dementia. It was proposed that this syndrome of parkinsonian dementia is related to the consumption of flour made from cycad seeds [35] or to inhalation of pollen from cycad plants [36]. Later findings suggest that a neurotoxic non-protein amino acid, beta-methylaminoL-alanine synthesized by a symbiotic cyanobacterium highly present on cycad seeds and pollen is actually responsible for this effect [37].

Remarkably, in some populations there has been a decreasing prevalence of certain types of neurodegenerative diseases that coincide with the disappearance of an environmental factor unique to these populations [38,39].

Together with exposure to environmental toxins, PD has been related to head trauma [40-43], inflammation $[44,45]$ and constipation [46]. While head trauma and inflammation are associated with vascular and postencephalitic parkinsonisms with a lower progression rate (around 50\%) to higher nervous structures [47], constipation is associated with $\mathrm{PPD}$ and patients present pathology progression. We hypothesize that, in these cases, a decreased frequency of bowel movements might increase the time that environmental toxins remain in the intestine and can interact with the organism.

As a counterbalance, certain factors have been associated with a decreased risk of developing PD. Cigarette smoking, coffee drinking and high levels of urate in blood have been negatively correlated with the appearance of PD [48-50]. The mechanisms underlying such protection are still unclear.

Therefore, the question is, can the interaction with environmental toxins explain the distribution and appearance pattern of PD clinical symptoms and pathology in non-genetic cases?

\section{Clinicopathological correlation in Parkinson's disease}

PD is traditionally defined by a series of clinical symptoms. These are predominantly motor disorders that give rise to the rigid-akinetic syndrome. PD is the main aetiology of rigid-akinetic syndromes. Nevertheless, nonmotor symptoms are widely distributed in PD patients.

The pathophysiological implications of PD-related alterations depend on the structures affected at each stage. The main pathological findings in PD are the presence of Lewy Bodies (LB) or neurites (LN) and the loss of chatecholaminergic neurons in the locus coeruleus and the substantia nigra (SN). The classical appearance of the $\mathrm{LB}$ in pigmented neurons with hematoxylin/eosin staining is that of one or more eosinophilic spherical body with a dense core surrounded by a halo [51]. Lewy bodies are intracytoplasmatic protein accumulations consisting mainly in alpha-synuclein [52]. Based on their findings and that from others at that time, Braak and colleagues suggested that, in iPD, the pathology follows a specific progression pattern appearing first in the olfactory bulb $(\mathrm{OB})$ and the dorsal motor nucleus of the vagus (DMV) [53,54], giving rise to Braak's pathological staging of PD (Figure 1). Interestingly, similar studies had shown that LB and LN could be observed in the peripheral nervous system (PNS) including the enteric nervous system (ENS) [55,56], the sympathetic ganglia [55], the submandibular glands [57] and the cardiac plexus [58] among others. Further pathological studies observed that other central nervous system sites (i.e. the intermediolateral column and the lamina I of the posterior horn from the spinal cord) also show LBs and LNs in the initial stages of the disease. The order of appearance of the pathology throughout all these sites made Braak's group incorporate this to their staging and established a new pathological staging including the sympathetic and parasympathetic systems and the ENS. The spatio-temporal pattern of this staging suggests that iPD-related alterations appear first in the ENS and the OB progressing into and throughout the CNS. This progression correlates well with the evolution of the clinical symptoms observed in iPD patients.

Corresponding to structural alterations, there are motor and non-motor symptoms in iPD. The onset of motor features correlates with the loss of dopamine input to the posterior putamen, corresponding to the motor region of the striatum. The main classical features of PD are therefore mainly related to the dysfunction of the motor circuit. As the disease progresses and the loss of dopaminergic neurons increases, the dopaminergic input to other areas of the striatum and the cortex (prefrontal and limbic circuits) decreases, giving rise to clinical symptoms characteristic of the dysfunction of higher cerebral structures.

Less frequent motor-symptoms that can be found in PD patients are hypophonia, taquiphemia, drooling, dysphagia, fatigue (can also be considered a non-motor symptom), hypomimia, impaired fine motor dexterity and motor coordination, impaired gross motor coordination, akathisia and palilalia. Most of these less frequent motor-symptoms seem to be expressions of the same pathophysiological alterations described above for the main motor symptoms.

Non-motor symptoms are believed to derive from the degeneration of non-dopaminergic (i.e. noradrenergic, serotoninergic and cholinergic) cellular systems. This can be applied to dementia, depression, sleep and vegetative disorders. It is known that almost $90 \%$ of PD patients experience non-motor manifestations during the course of disease [59] and are a significant economic burden [60] (with a substantial impact on the health-related quality of life). Further clinical studies show that a loss of olfaction, rapid eye movement (REM) sleep behaviour disorders and 
A

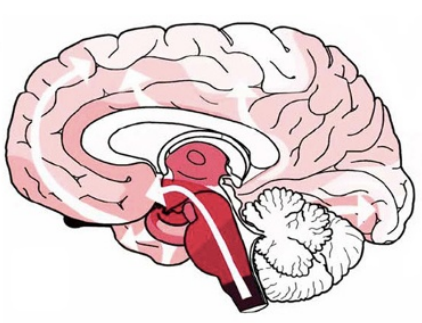

C

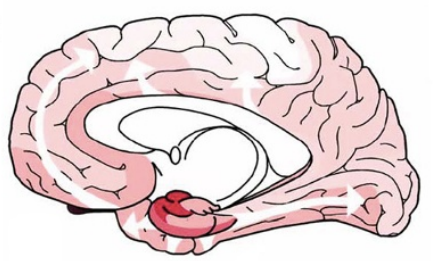

B

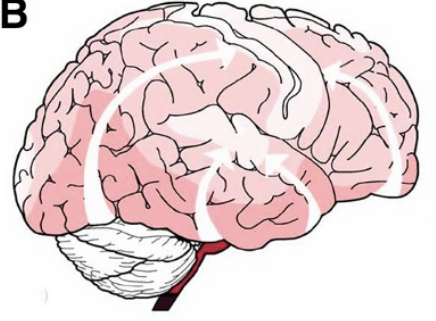

D

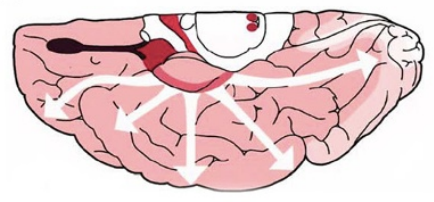

$\mathrm{E}$

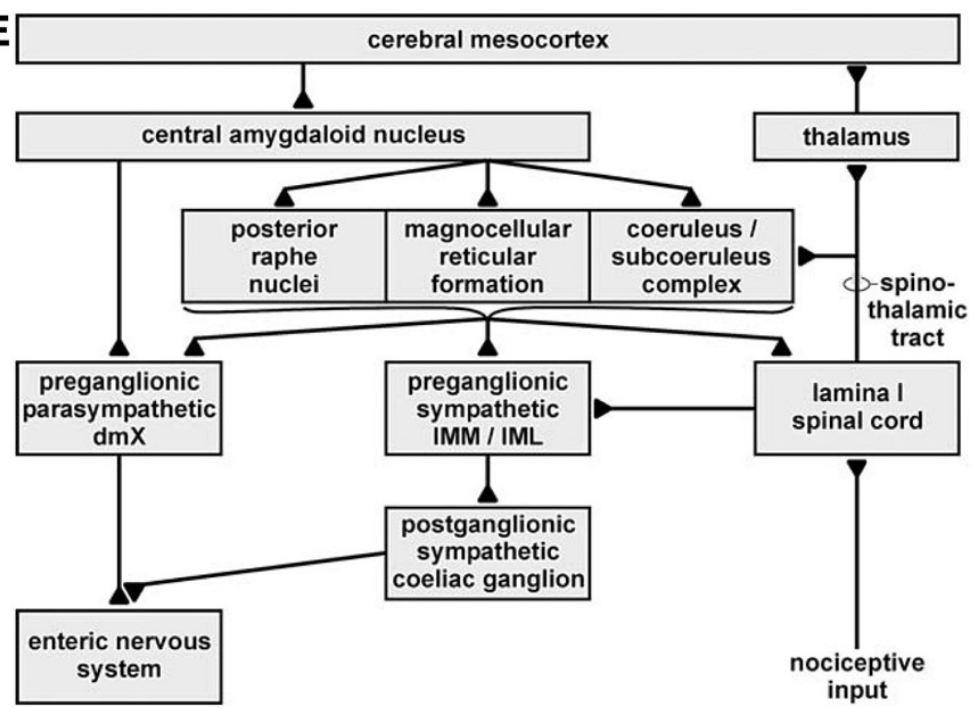

$\mathbf{F}$

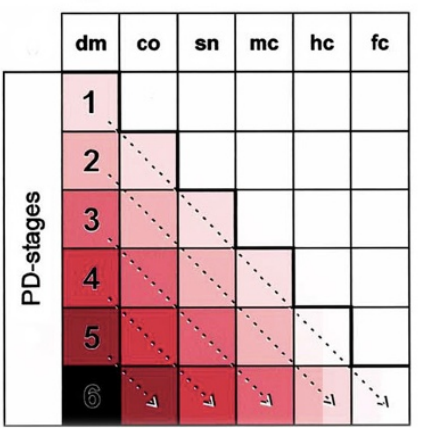

Figure 1 Braak's staging of Parkinson's disease pathology progression. (A-D) Illustrations showing the intracerebral progression of PD pathology. (E) Schematics of the pathology progression from the ENS. (F) Correlation between PD staging and the appearance of the pathology in different intracerebral structures. Modified from Braak et al. [53].

constipation anticipate motor-problems [61]. All this suggests that PD is a progressive disease, which might originate at the olfactory bulb and the ENS. Recent follow-up studies have successfully investigated the use of hyposmia/anosmia or REM sleep behaviour as early signs for PD and to test pre-motor symptoms of the disease [61-64]. Interestingly, the ENS and the $\mathrm{OB}$ are the nervous system structures most exposed to environmental toxins. Therefore, it seems possible that the effect of these substances on these structures could trigger the appearance and progression of the disease. 


\section{Genetic forms of Parkinson's disease}

Despite all this body of evidence, the relatively low incidence of PD suggests that the individual genetic background plays an important role in the pathogenesis of the disease. What are the genetic alterations that predispose to the development of PD and why?

Already a century ago it was noticed that PD patients had affected relatives [65]. The role of genetic inheritance in PD has been increasingly important during the past couple of decades because of different studies. Despite the complexity of achieving good quality epidemiologic studies due to diagnostic difficulties, different studies have confirmed that PD is more common between family members [66-70]. Generally, the risk of having the disease among relatives is 2 to 3 times greater than in the general population [4]. Also, studies on homozygotic twins have shown that although there is no significant concordance in late onset disease cases [71], it becomes significant in early onset cases. Therefore, one could say that early PD is usually genetically determined.

In the last decades, there has been an increase in the number of PD family based studies [4,67,72-82]. Most of these show an autosomic pattern, either dominant or recessive. These studies have been able to identify some genetic mutations and chromosomal loci responsible for familiar PD. The most studied and known mutations are annotated in Table 1. Interestingly, a recent meta-analysis on more than 800 published genetic associations studies revealed eleven loci showing genome-wide significant association with disease risk: BST1, CCDC62/HIP1R, DGKQ/ GAK, GBA, LRRK2, MAPT, MCCC1/LAMP3, PARK16, SNCA, STK39, and SYT11/RAB25. In addition, they identified novel evidence for genome-wide significant association with a polymorphism in ITGA8 [83]. The list of hits is available under www.pdgene.org.

Animal genetic models of the disease have been important to better understand the mechanisms underlying
PD pathophysiology. Different animal models mimicking the genetic alterations observed in PD patients have been developed in organisms such as mice, worms, flies or zebrafish [85-88]. These include the knock-out, over-expression or expression of mutated forms of PARK-1 (i.e. alpha-synuclein or its $A 53 T, A 30 P$, and $E 46 K$ mutations) or the knock-down of DJ-1, PINK or LRRK2 (G2019S and R1441C/G mutants) [85,89] among others. However, most of these models failed to reproduce overt nigrostriatal dopaminergic loss having wider effects throughout the CNS. In some cases, these genetic alterations even had a neuroprotective effect (e.g. over-expression of wild-type alphasynuclein) $[90,91]$. Moreover, genetic mutations in PD account for less than $10 \%$ of the patients and cannot explain many of the clinical and pathological signs observed in idiopathic PD patients. Thus, it seems that environmental toxins might be playing a more important role than previously thought.

\section{Evidence obtained using toxic models of PD}

Based on the above-mentioned observations, numerous groups have tested the effect of environmental toxins on animal and in vitro cellular models. The most common models used up to date are:

\section{Animal models}

These have been extensively reviewed in the literature [92-94] and we will briefly describe some of them here.

\section{1-methyl-4-phenyl-1,2,3,6-tetrahydropyridine (MPTP)}

MPTP is a non-toxic compound that may be accidentally produced during the manufacture of MPPP, a synthetic opioid drug. In the 80ies, several cases of Parkinson after the accidental ingestion of MPTP were described $[95,96]$. When ingested, it is metabolized into the toxic cation 1-methyl-4-phenylpyridinium $\left(\mathrm{MPP}^{+}\right)$by the enzyme MAO-B of glial cells. MPP + is a potent mitochondrial

Table 1 Known genetic mutations in PD

\begin{tabular}{|c|c|c|c|c|c|}
\hline Locus & Chromosome'Location & Gene & Inheritance & Typical pheno-type & Reference \\
\hline PARK1 \& PARK4 & $4 q 21-q 23$ & a-synuclein & $A D$ & Earlier onset, features of DLB'common & {$[72,73]$} \\
\hline PARK2 & $6 q 25.2-q 27$ & parkin & usually AR & Earlier onset with slow progression & [74] \\
\hline PARK3 & $2 p 13$ & unknown & $A D, I P$ & Classic PD,'sometimes de-mentia & [4] \\
\hline PARK5 & $4 p 14$ & UCH-L1 & $A D$ & Classic PD & [75] \\
\hline PARK6 & 1p35-p36 & PINK1 & AR & Earlier onset with'slow progression & [76] \\
\hline PARK7 & $1 p 36$ & DJ-1 & AR & Earlier onset with'slow progression & {$[67]$} \\
\hline PARK8 & 12p11.2-q13.1 & LRRK2 & $A D$ & Classic PD & [77] \\
\hline PARK10 & $1 \mathrm{p} 32$ & unknown & Unclear & Classic PD & [78] \\
\hline PARK11 & $2 q 36-q 37$ & unknown & Unclear & Classic PD & [79] \\
\hline NA & $5 q 23.1-q 23.3$ & Synphilin1 & Unclear & Classic PD & [80] \\
\hline NA & $2 q 22-q 23$ & NR4A2 & Unclear & Classic PD & [81] \\
\hline
\end{tabular}

Abbreviations: NA not assigned, $A D$ autosomic dominant, $A R$ autosomic recesive, IP incomplete penetrante, DLB Lewy Bodies Demence. Modified from [84]. 
Complex I inhibitor that primarily kills dopaminergic neurons [97]. Models based on this substance have been used to understand the effect of mitochondrial inhibition, to test different neuroprotective strategies or to observe the effect of dopamine absence in different brain functions and areas [98,99]. As PD model, it presents two main problems. First, MPTP induces an acute or subacute neurodegeneration, different to the chronic PD process and second, there is no LB formation [100] and no pathology progression has been observed so far.

\section{6-hydroxydopamine (6-OHDA)}

6-OHDA Treatment led to the first known animal model of PD [101,102]. 6-OHDA is injected into the medial forebrain bundle of rat brain (destroying dopamine neurons in the substantia nigra pars compacta with the subsequent loss of dopamine nerve terminals in the striatum $[101,102]$. The unilaterally lessoned animals circle toward their lesioned side. This is driven by the asymmetric release of dopamine from the intact side of striatum [101]. 6-OHDA generates quinones inside the neurons. These quinones generate free radicals that inactivate biological macromolecules. It is necessary to inject 6-OHDA directly in the central nervous system (CNS), as it is not able to cross the brain-blood barrier. As in the case of MPTP, this model does not produce the characteristic LB nor does it show pathology progression.

\section{Paraquat}

Paraquat is a herbicide that induces dopaminergic degeneration and LB formation in the SN of mice [103]. Its parenteral administration produces its effect by inducing superoxide radical formation. However, it is not known whether this effect is local on SN neurons or also other cell types might be affected. Moreover, pathology progression has not been reported.

\section{Rotenone}

Rotenone is a naturally occurring pesticide derived from the roots of certain plant species that acts through mitochondrial Complex I inhibition. Rotenone has been used through non-natural ways of administration such as direct nigrostriatal infusion and systemic intraperitoneal or intravenous administration to generate toxic models of PD in rats and mice [104-107]. To achieve a more natural way of exposure to environmental toxins, two groups have used orally administered rotenone to generate PD-like pathology and symptoms in mice $[108,109]$.

Systemic chronic administration (more the 5 weeks) of rotenone induces specific dopaminergic neuron degeneration with the formation of LB-like alpha-synuclein inclusions [104]. Moreover, high doses of rotenone lead to a striatal degeneration without SN impairment [110], showing the same degeneration pattern as in manganese and carbon monoxide exposure in primates and humans. However, systemic administration of this substance mimics a multisytemic degeneration rather than the degeneration pattern observed in PD patients [111].

Oral administration of rotenone induces different effects depending on the concentration at which it is administered. Inden and colleagues have shown that high doses ( $>5 \mathrm{mg} / \mathrm{kg}$ ) of orally administered rotenone affect SN dopaminergic neurons one month after administration [108]. In a later study, we showed that at these high doses, dopaminergic degeneration was due to the presence of rotenone in the systemic blood [109]. Interestingly, in this same study we showed that long-time exposure to low doses of orally administered rotenone induced the appearance of PD-like pathology and its progression from the ENS into the CNS accompanied by dopaminergic loss in the SN. We did not observe systemic Complex I inhibition or the presence or rotenone in the blood or the brain. Thus, suggesting that, as the ENS and the OB are the nervous structures most exposed to environmental toxins, environmental toxins acting locally on these nervous structures trigger the appearance of PD-like pathology and its progression into the CNS through synaptically connected structures. Indeed, in a recent study, we have shown that the resection of the vagal or sympathetic nerves (connecting the ENS to the CNS) interrupts the progression of the pathology to the previously connected structures [112]. Interestingly, the co-treatment with a compound inhibiting alpha-synuclein aggregation also reduced the effect of oral administered rotenone [113].

\section{In vitro cellular models}

In vitro systems are very efficient screening tools for detecting potential neurotoxic compounds among the multitude of chemicals to which humans are exposed. They also offer many opportunities to investigate the cellular and molecular effects of toxins. Studies performed in primary neuronal cultures and both PC12 and SH-SY5Y cell lines have been used to test different compounds potentially involved in neurodegeneration. For example, aluminium, copper and iron, as well as several pesticides were shown to trigger structural transformation and fibrillation of alpha-synuclein $[114,115]$. A dithiocarbamate fungicide altered the function of the ubiquitin-proteasome system by inhibition of the ubiquitin E1 ligase [116] and different reports show that xenobiotics induce oxidative stress. Evidence for oxidative stress was also found in vitro in primary cultures of cerebellar granule neurons after exposure to numerous pesticides and insecticides [117] and [118], in PC12 cells after exposure to trimethyltin [119], in primary cultures of mesencephalic neurons after exposure to ethylene-bis-dithiocarbamate fungicide [120], and in 
midbrain slice cultures after exposure to the pesticide rotenone [106].

In vitro, environmental compounds have also been shown to induce glial reactivity, a crucial step of the brain inflammatory pathway. After subchronic exposure to mercury compounds, microgliosis and astrogliosis were found in aggregating brain cell cultures, without any sign of neuronal damage [121,122].

\section{Is there a common toxic mechanism in all these models that leads to neurodegeneration?}

One of the common effects exerted by most of these noxious compounds tested above is the inhibition of mitochondrial NADH $\mathrm{CoQ}$ reductase, also known as Complex I, and the production of free radicals, thereby also increasing cellular oxidative stress. The first association between a mitochondrial alteration and PD was made in 1989. Two different groups showed a defect in Complex I activity from SN neurons in PD patients [123]. Later studies have shown that there is an approximately $35 \%$ defect in the mitochondrial complex I activity [124]. This deficiency is also present in platelets from PD patients [125]. As mentioned above, a study published in 2011 underlines the importance of Complex I inhibition and oxidative stress in PD pathophysiology in patients. In an epidemiological study, Tanner and colleagues observed in 110 PD cases and 358 controls that PD was strongly associated with the use of a group of pesticides that inhibit mitochondrial complex I, including rotenone, and with the use of a group of pesticides that cause oxidative stress, including paraquat [30].

Oxidative stress leads to the production of reactive oxygen species (ROS) and has been linked to PD [126]. ROS can modify lipids and proteins (e.g. acetylation and phosphorylation) thereby altering their normal folding and degradation. Different studies have shown that inhibition of mitochondrial Complex I enhances oxidative stress hence increasing autophagy [127]. Interestingly, we have shown that rotenone induces the accumulation and release of alpha-synuclein from enteric neurons into the extracellular space [112]. Using an in vitro system mimicking the sympathetic innervation of the gut, we also showed that released alpha-synuclein can be retrogradely transported and accumulated in the soma of the host neurons. All this is summarized in Figure 2.

This could also explain the results from some recent pathological studies performed on PD patients that had previously received intrastriatal embryonic cellular transplants. In these patients, grafted neurons showed alpha-synuclein inclusions similar to those observed in the surrounding neurons $[128,129]$. Recent in vivo and in vitro studies in mice could give some hints on the mechanism underlying this intra-neuronal transmission of the pathology. Desplats and colleagues have shown that alpha-synuclein is transported from the host to grafted neurons in mice and between cells in co-culture [130]. Using Thy-1 $\alpha$-synuclein transgenic mice, they performed stereotaxic intrahippocampal injections of GFP-expressing mouse cortical neuronal stem cells. In vitro, they used differentiated SH-SY5Y neuronal cells over-expressing myc-tagged $\alpha$-synuclein co-cultured with non-transfected SH-SY5Y cells. After some time, both grafted GFP cells and non-transfected SH-SY5Y showed alpha-synuclein inclusions. These were tyramide red or myc positive, thus demonstrating that they had been intracellularly transported. They seemed to have an enucleating effect. A later study performed by AlvarezErviti and colleagues showed that alpha-synuclein overexpression in SH-SY5Y induced lysosomal dysfunction and increased the release of exosomes containing alphasynuclein to the media [131].

Finally, environmental toxins can also induce the release of pro-inflammatory signals. Observed in other neurological diseases like stroke, there is evidence for an increased inflammatory response in PD patients with microglial activation and inflammatory cytokine production [132-135]. The inflammation of the brain in early life caused by exposure to toxins, or environmental factors, has been suggested as a possible cause or contributor to the later development of PD [136]. The inflammatory process in such cases may involve activation of brain immune cells (microglia and astrocytes), which release inflammatory and neurotoxic factors that in turn produce neurodegeneration [44]. This concept first arose in the suggestion that infection with influenza virus in the pandemic of 1918 produced an increased risk of PD. Infection with certain microorganisms such as the soil bacterium Nocardia asteroides has been proposed as a risk factor for PD [137]. In animal experiments, exposure to the bacterial endotoxin lipopolysaccharide induced dopaminergic neurodegeneration $[136,138,139]$. However, it has been impossible to detect the presence of viral and bacterial DNA or other components inside the nervous system of PD patients. We have now clear evidence of an increased inflammatory response in PD patients with microglial activation and inflammatory cytokine production $[132,140]$. It has been proven that this process is due to i) the release of pro-inflammatory cytokines under oxidative stress [141] and ii) extracellular alpha-synuclein that can also promote by itself the appearance of an inflammatory reaction [142]. The real role and magnitude of this inflammatory response is unknown, but some authors maintain that they do play an important role in PD pathophysiology by perpetuating the process and causing further damages [143].

Therefore, it is likely that external factors trigger the appearance of the disease in these individuals. In fact, there are striking similarities in the effect of both mutations and environmental toxins that could explain this increased sensitivity and give hints on the pathophysiological process in PD. 


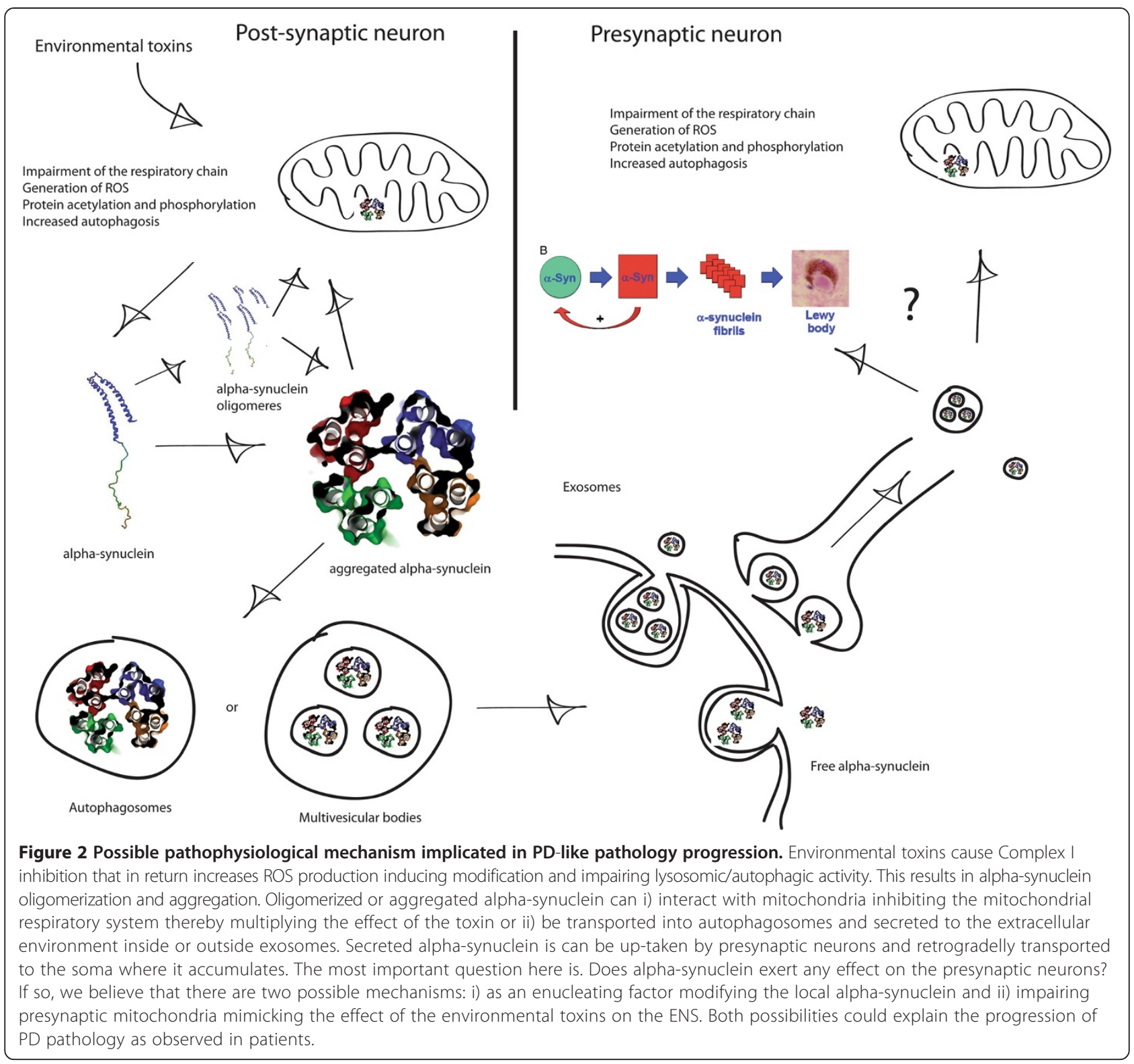

\section{Gene-environment interactions}

The known genetic mutations associated with PD can be grouped in three categories: alpha-synuclein mutations (E46K, A30P and A53T) and over-expression (mutations in $P A R K-1$ ), defects in protein degradation (mutations in $P A R K-2$ and $P A R K-5)$ and increases in oxidative stress (mutations in PARK-6 and PARK-7). The latter one leads to protein modifications, impairment of protein degradation and increases in alpha-synuclein release [76].

If we compare the alterations induced by PD-related mutations and the exposure to pesticides, it becomes clear that there are striking similarities. Impairment of mitochondrial function, protein modifications (phosphorylations and acetylations), alterations in protein degradation or the release of pro-inflammatory signals are common to many of these mutations. These alterations are also related to each other. Mitochondrial dysfunction can induce alterations in proteins and the release of pro-inflammatory signals as well as lysosomal impairment [144]. Altered proteins cannot be properly degraded and it is known that, at least one (i.e. alpha-synuclein) can induce mitochondrial dysfunction. It has been shown that both over-expression of alpha-synuclein and inhibition of mitochondrial respiration impair the lysosomal system and induce the release of alpha-synuclein to the extracellular matrix. Extracellular alpha-synuclein can then be up-taken by presynaptic neurons, where it accumulates and might impair mitochondrial function [145-147]. It has also been shown that extracellular alpha-synuclein induces an inflammatory reaction [148]. Finally, it is known 
that recruited inflammatory cells (i.e. microglia) further damage neuronal cells and induce oxidative stress through the release of superoxides and their phagocytic activity [143].

All this suggests that individuals carrying PD-related mutations might be more sensitive to environmental toxins and develop the disease at earlier stages of life.

In the last decade, there have been a number of studies aiming at analysing environmental damages on different genetic backgrounds. It has been shown that lipopolysaccharides enhance dopaminergic death in mice overexpressing human alpha-synuclein or its mutated forms and in Parkin-deficient mice $[143,149,150]$. The same kind of experiments using intraperitoneal injections of different neurotoxins has led to contradictory results. Paraquat, rotenone, maneb or MPTP had different effects on mice expressing human-alpha-synuclein or its mutated forms (i.e. A53T and A30P). In mice expressing A53T alpha-synuclein only a combination of maneb and paraquat, but not each of them alone, lead to an increased alpha-synuclein pathology throughout the CNS when compared to wild-type littermates [151]. Paraquat treatment on mice expressing human-alpha-synuclein or human-A53T-alpha-synuclein under a TH promoter increased alpha-synuclein pathology [152]. However, dopaminergic degradation was observed only in wild-type mice. This same treatment on DJ-1 mice showed that the dopaminergic neurons of these mice have an increased sensitivity to paraquat [153]. Similarly, LRRK-2 knock-out mice were as sensitive to neurotoxins as their wild-type littermates. Remarkably, it seems that, while increasing alpha-synuclein levels and the presence of alpha-synuclein pathology, these genetic backgrounds had either a protective or no effect on the susceptibility to environmental toxins.

Genetic studies have also shown that there are certain epigenetic modifications in the DNA, both nuclear and mitochondrial, of blood leucocytes and neurons from PD patients [154]. The majority of epigenetic alterations consist on methylations and alterations in the microRNA expression [154-156]. Some authors have tried to reverse these effects through the use of histone deacetylase inhibitors with different results (reviewed in [157]). It may well be that short exposure to pesticides can trigger permanent epigenetic modifications playing a role in the development of the disease.

Conclusion: can we imply an environmental origin of PD? Overall, all this body of evidence strongly suggest that environmental insults may play an important role in the appearance and progression of PD pathology. This is especially true for iPD. In these patients, the progression of the pathology may start from the ENS and OB and follows a predictable spatiotemporal pattern. Interestingly, these are the two nervous structures most exposed to environmental toxins and in vitro and in vivo studies suggest that environmental toxins acting on the ENS could initiate the pathology and trigger its progression through the release and transcellular transport of alphasynuclein. This kind of progression mechanism could also explain the pattern observed in other neurodegenerative diseases. Supporting this hypothesis, a prion-like behaviour of an amyloid was characterized in Alzheimer's disease in a recent study from Nussbaum and colleagues [158].

Despite this positive correlation with environmental toxins, to hypothesize that PD could be triggered only by exposure to environmental toxins would be, to say the least, naive. The onset of most diseases is due to a combination of external aggressors and individual genetic susceptibility to this aggression. This is clearly also the case for PD. The low incidence of PD suggests that differences in the individual genetic background and gene-environment interactions play an important role in the whole process. Results coming from different studies using neurotoxins in transgenic mice remain controversial. However, it may well be that the toxic models used up-to-date are not the ideal ones. Systemic injections of neurotoxins do not mimic the natural ways of exposure to these substances. The use of oral administered or inhaled neurotoxins may lead to different kind of results. We find very interesting that all neurotoxins used on different PD-related backgrounds induced an up-regulation of alpha-synuclein and an increase in LB-like inclusions. This is normally correlated to an increased exocytosis of alpha-synuclein [130,131] that, as mentioned above, has been shown to play a role in the progression of PD pathology. On the other hand, analysis of other types of genes (i.e. genes responsible for the protection against oxidative stress and genes coding for detoxifying enzymes) in different regions from those "a priori" expected (i.e. the ENS, the $\mathrm{OB}$ and the intestine) could reveal new mutations responsible for a higher susceptibility to the effect of environmental toxins. However, the new available data strongly suggests that the implications of these toxins in idiopathic PD are not merely testimonial. To consider PD mainly as a genetic disease subjected to minor external influence is akin to neglecting the effect of tobacco on lung cancer.

\footnotetext{
Abbreviations

PD: Parkinson's disease; iPD: Idiopathic Parkinson's disease; MPTP: 1-methyl-4phenyl-1,2,3,6-tetrahydropyridine; MPP+: 1-methyl-4-phenylpyridinium; 6-OHDA: 6-hydroxydopamine; CNS: Central nervous system; LB: Lewy bodies; LN: Lewy neurites; SN: Substantia nigra; OB: Olfactory bulb; DMV: Dorsal motor nucleus of the vagus; PNS: Peripheral nervous system; ENS: Enteric nervous system; REM: Rapid Eye Movement; ROS: Reactive oxygen species.
} 
Authors' contributions

FP-M and HR wrote the manuscript. Both authors read and approved the final manuscript.

\section{Acknowledgements}

We would like to thank Prof. Juan Pan-Montojo at the Department of Modern History at the Universidad Autónoma de Madrid for his help with the references related to the evolution of life expectancy throughout history, critical reading of the manuscript and stimulating scientific discussions. Dr. Alex Kalinka at the Max-Planck Institute for Cell Biology and Genetics in Dresden for the critical reading of the manuscript.

\section{Author details}

${ }^{1}$ Neurologische Klinik, Klinikum der Ludwig-Maximilians-Universität München, Marchioninistr. 15, 81377 Munich, Germany. ${ }^{2}$ Munich Cluster for Systems Neurology (SyNergy), Adolf-Butenandt-Institut Ludwig-Maximilians-Universität München, Schillerstr. 44, 80336 Munich, Germany. ${ }^{3}$ Klinik und Poliklinik für Neurologie, Carl Gustav Carus University Hospital, TU-Dresden, Fetscherstr. 74, 01307 Dresden, Germany.

Received: 3 February 2014 Accepted: 29 April 2014

Published: 9 May 2014

\section{References}

1. Checkoway $H$, Nelson LM: Epidemiologic approaches to the study of Parkinson's disease etiology. Epidemiology 1999, 10:327-336.

2. Twelves D, Perkins KS, Counsell C: Systematic review of incidence studies of Parkinson's disease. Mov Disord 2003, 18:19-31.

3. de Rijk MC, Launer L, Berger K, Breteler MM, Dartigues JF, Baldereschi M, Fratiglioni L, Lobo A, Martinez-Lage J, Trenkwalder C, Hofman A: Prevalence of Parkinson's disease in Europe: A collaborative study of population-based cohorts. Neurologic Diseases in the Elderly Research Group. Neurology 2000, 54:S21-S23.

4. Gasser T: Genetics of Parkinson's disease. Clin Genet 1998, 54:259-265.

5. Bekris LM, Mata IF, Zabetian CP: The genetics of Parkinson disease. J Geriatr Psychiatry Neurol 2010, 23:228-242.

6. Ben-Shlomo Y: The epidemiology of Parkinson's disease. Baillieres Clin Neurol 1997, 6:55-68.

7. Tanner CM, Ben-Shlomo Y: Epidemiology of Parkinson's disease. Adv Neurol 1999, 80:153-159.

8. Kondo K: Rising prevalence of neurodegenerative diseases worldwide. Intern Med 1996, 35:238.

9. Baldi I, Cantagrel A, Lebailly P, Tison F, Dubroca B, Chrysostome V, Dartigues JF, Brochard P: Association between Parkinson's disease and exposure to pesticides in southwestern France. Neuroepidemiology 2003, 22:305-310.

10. Freire C, Koifman S: Pesticide exposure and Parkinson's disease: epidemiological evidence of association. Neurotoxicology 2012, 33:947-971.

11. Gorell JM, Johnson CC, Rybicki BA, Peterson EL, Richardson RJ: The risk of Parkinson's disease with exposure to pesticides, farming, well water, and rural living. Neurology 1998, 50:1346-1350.

12. Gourie-Devi M, Ramu MG, Venkataram BS: Treatment of Parkinson's disease in 'Ayurveda' (ancient Indian system of medicine): discussion paper. J R Soc Med 1991, 84:491-492.

13. Zhang ZX, Dong ZH, Roman GC: Early descriptions of Parkinson disease in ancient China. Arch Neurol 2006, 63:782-784.

14. Calne DB, Langston JW: Aetiology of Parkinson's disease. Lancet 1983, 2:1457-1459.

15. de Lau LM, Breteler MM: Epidemiology of Parkinson's disease. Lancet Neurol 2006, 5:525-535.

16. Federico A, Cardaioli E, Da Pozzo P, Formichi P, Gallus GN, Radi E: Mitochondria, oxidative stress and neurodegeneration. J Neurol Sci 2012 322:254-262.

17. Wilmoth JR: Methods protocol for the human mortality database. In Book Methods Protocol for the Human Mortality Database; 2002. (Editor ed.^eds.). City.

18. Goerlich Gisbert FJAPP: Esperanza de vida en España a lo largo del siglo XX. BBVA 2006, 1:5-43.

19. Kamel F, Tanner C, Umbach D, Hoppin J, Alavanja M, Blair A, Comyns K, Goldman S, Korell M, Langston J, Ross G, Sandler D: Pesticide exposure and self-reported Parkinson's disease in the agricultural health study. Am J Epidemiol 2007, 165:364-374.
20. Ranga Rao GV RO, Rameshwar Rao V, Reddy YVR: Role of biopesticides in crop protection: present status and future prospects. Indian J Plant Prot 2007, 35:1-9.

21. Metcalf RL: Organic Insecticides: Their Chemistry and Mode of Action. New York: Interscience Publishers, Inc.; 1955.

22. Liou HH, Tsai MC, Chen CJ, Jeng JS, Chang YC, Chen SY, Chen RC: Environmental risk factors and Parkinson's disease: a case-control study in Taiwan. Neurology 1997, 48:1583-1588.

23. Priyadarshi A, Khuder SA, Schaub EA, Priyadarshi SS: Environmental risk factors and Parkinson's disease: a metaanalysis. Environ Res 2001, 86:122-127

24. Lai BC, Marion SA, Teschke K, Tsui JK: Occupational and environmental risk factors for Parkinson's disease. Parkinsonism Relat Disord 2002, 8:297-309.

25. Rajput AH, Uitti RJ, Stern W, Laverty W: Early onset Parkinson's disease in Saskatchewan-environmental considerations for etiology. Can J Neurol Sci 1986, 13:312-316.

26. Behari M, Srivastava AK, Das RR, Pandey RM: Risk factors of Parkinson's disease in Indian patients. J Neurol Sci 2001, 190:49-55.

27. Seidler A, Hellenbrand W, Robra BP, Vieregge P, Nischan P, Joerg J, Oertel WH, Ulm G, Schneider E: Possible environmental, occupational, and other etiologic factors for Parkinson's disease: a case-control study in Germany. Neurology 1996, 46:1275-1284

28. Semchuk KM, Love EJ, Lee RG: Parkinson's disease and exposure to agricultural work and pesticide chemicals. Neurology 1992, 42:1328-1335

29. Fleming L, Mann JB, Bean J, Briggle T, Sanchez-Ramos JR: Parkinson's disease and brain levels of organochlorine pesticides. Ann Neurol 1994, 36:100-103.

30. Tanner CM, Kamel F, Ross GW, Hoppin JA, Goldman SM, Korell M, Marras C, Bhudhikanok GS, Kasten M, Chade AR, Comyns K, Richards MB, Meng C, Priestley B, Fernandez HH, Cambi F, Umbach DM, Blair A, Sandler DP, Langston JW: Rotenone, paraquat, and Parkinson's disease. Environ Health Perspect 2011, 119:866-872.

31. Champy P, Hoglinger GU, Feger J, Gleye C, Hocquemiller R, Laurens A, Guerineau V, Laprevote O, Medja F, Lombes A, Michel PP, Lannuzel A, Hirsch EC, Ruberg M: Annonacin, a lipophilic inhibitor of mitochondrial complex I, induces nigral and striatal neurodegeneration in rats: possible relevance for atypical parkinsonism in Guadeloupe. J Neurochem 2004 88:63-69.

32. Huang CC, Lu CS, Chu NS, Hochberg F, Lilienfeld D, Olanow W, Calne DB: Progression after chronic manganese exposure. Neurology 1993, 43:1479-1483.

33. Needleman H, Landrigan PJ: Toxins at the pump. New York Times 1996, :15.

34. Richardson JR, Roy A, Shalat SL, Buckley B, Winnik B, Gearing M, Levey Al, Factor SA, O'Suilleabhain P, German DC: Beta-hexachlorocyclohexane levels in serum and risk of Parkinson's disease. Neurotoxicology 2011 32:640-645.

35. Brownson DM, Mabry TJ, Leslie SW: The cycad neurotoxic amino acid, beta-N-methylamino-L-alanine (BMAA), elevates intracellular calcium levels in dissociated rat brain cells. J Ethnopharmacol 2002, 82:159-167.

36. Seawright AA: Directly toxic effects of plant chemicals which may occur in human and animal foods. Nat Toxins 1995, 3:227-232. discussion 242

37. Bradley WG, Mash DC: Beyond Guam: the cyanobacteria/BMAA hypothesis of the cause of ALS and other neurodegenerative diseases. Amyotroph Lateral Scler 2009, 10(Suppl 2):7-20.

38. Kurland LT, Mulder DW: Epidemiologic investigations of amyotrophic lateral sclerosis. I. Preliminary report on geographic distribution and special reference to the Mariana Islands, including clinical and pathologic observations. Neurology 1954, 4:438-448.

39. Plato CC, Garruto RM, Galasko D, Craig UK, Plato M, Gamst A, Torres JM, Wiederholt W: Amyotrophic lateral sclerosis and parkinsonism-dementia complex of Guam: changing incidence rates during the past 60 years. Am J Epidemiol 2003, 157:149-157.

40. Doder M, Jahanshahi M, Turjanski N, Moseley IF, Lees AJ: Parkinson's syndrome after closed head injury: a single case report. J Neurol Neurosurg Psychiatry 1999, 66:380-385.

41. Nayernouri T: Posttraumatic parkinsonism. Surg Neurol 1985, 24:263-264.

42. Goldman SM, Tanner CM, Oakes D, Bhudhikanok GS, Gupta A, Langston JW: Head injury and Parkinson's disease risk in twins. Ann Neurol 2006, 60:65-72.

43. Jafari S, Etminan M, Aminzadeh F, Samii A: Head injury and risk of Parkinson disease: a systematic review and meta-analysis. Mov Disord 2013, 28:1222-1229. 
44. Liu B, Hong JS: Role of microglia in inflammation-mediated neurodegenerative diseases: mechanisms and strategies for therapeutic intervention. J Pharmacol Exp Ther 2003, 304:1-7.

45. Ghaemi M, Rudolf J, Schmulling S, Bamborschke S, Heiss WD: FDG- and Dopa-PET in postencephalitic parkinsonism. J Neural Transm 2000, 107:1289-1295.

46. Abbott RD, Petrovitch H, White LR, Masaki KH, Tanner CM, Curb JD, Grandinetti A, Blanchette PL, Popper JS, Ross GW: Frequency of bowel movements and the future risk of Parkinson's disease. Neurology 2001, 57:456-462.

47. Selby G: The Graeme Robertson memorial lecture, 1983. The long-term prognosis of Parkinson's disease. Clin Exp Neurol 1984, 20:1-25.

48. Baron JA: Cigarette smoking and Parkinson's disease. Neurology 1986, 36:1490-1496.

49. Ascherio A, Zhang SM, Hernan MA, Kawachi I, Colditz GA, Speizer FE, Willett WC: Prospective study of caffeine consumption and risk of Parkinson's disease in men and women. Ann Neurol 2001, 50:56-63.

50. Weisskopf MG, O'Reilly E, Chen H, Schwarzschild MA, Ascherio A: Plasma urate and risk of Parkinson's disease. Am J Epidemiol 2007, 166:561-567.

51. Forno LS: Neuropathology of Parkinson's disease. J Neuropathol Exp Neurol 1996, 55:259-272.

52. Spillantini MG, Schmidt ML, Lee VM, Trojanowski JQ, Jakes R, Goedert M: Alpha-synuclein in Lewy bodies. Nature 1997, 388:839-840.

53. Braak H, Del Tredici K, Rub U, de Vos RA, Jansen Steur EN, Braak E: Staging of brain pathology related to sporadic Parkinson's disease. Neurobiol Aging 2003, 24:197-211.

54. Braak H, Ghebremedhin E, Rub U, Bratzke H, Del Tredici K: Stages in the development of Parkinson's disease-related pathology. Cell Tissue Res 2004, 318:121-134.

55. Wakabayashi K, Takahashi H: Neuropathology of autonomic nervous system in Parkinson's disease. Eur Neurol 1997, 38(Suppl 2):2-7.

56. Braak H, de Vos RA, Bohl J, Del Tredici K: Gastric alpha-synuclein immunoreactive inclusions in Meissner's and Auerbach's plexuses in cases staged for Parkinson's disease-related brain pathology. Neurosci Lett 2006, 396:67-72.

57. Del Tredici K, Hawkes CH, Ghebremedhin E, Braak H: Lewy pathology in the submandibular gland of individuals with incidental Lewy body disease and sporadic Parkinson's disease. Acta Neuropathol 2010, 119:703-713.

58. Orimo S, Amino T, Itoh Y, Takahashi A, Kojo T, Uchihara T, Tsuchiya K, Mori F, Wakabayashi K, Takahashi H: Cardiac sympathetic denervation precedes neuronal loss in the sympathetic ganglia in Lewy body disease. Acta Neuropathol 2005, 109:583-588.

59. Shulman LM, Taback RL, Bean J, Weiner WJ: Comorbidity of the nonmotor symptoms of Parkinson's disease. Mov Disord 2001, 16:507-510.

60. Chaudhuri KR, Martinez-Martin P: Quantitation of non-motor symptoms in Parkinson's disease. Eur J Neurol 2008, 15(Suppl 2):2-7.

61. Haehner A, Hummel T, Hummel C, Sommer U, Junghanns S, Reichmann H: Olfactory loss may be a first sign of idiopathic Parkinson's disease. Mov Disord 2007, 22:839-842.

62. Sommer U, Hummel T, Cormann K, Mueller A, Frasnelli J, Kropp J, Reichmann H: Detection of presymptomatic Parkinson's disease: combining smell tests, transcranial sonography, and SPECT. Mov Disord 2004, 19:1196-1202.

63. Ponsen MM, Stoffers D, Wolters E, Booij J, Berendse HW: Olfactory testing combined with dopamine transporter imaging as a method to detect prodromal Parkinson's disease. J Neurol Neurosurg Psychiatry 2010, 81:396-399.

64. Stiasny-Kolster K, Doerr Y, Moller JC, Hoffken H, Behr TM, Oertel WH, Mayer $\mathrm{G}$ : Combination of 'idiopathic' REM sleep behaviour disorder and olfactory dysfunction as possible indicator for alpha-synucleinopathy demonstrated by dopamine transporter FP-CIT-SPECT. Brain: a j neurol 2005, 128:126-137

65. Gowers W: Diseases of the nervous system. London: Chapman; 1888.

66. Payami H, Larsen K, Bernard S, Nutt J: Increased risk of Parkinson's disease in parents and siblings of patients. Ann Neurol 1994, 36:659-661.

67. Bonifati V, Fabrizio E, Vanacore N, De Mari M, Meco G: Familial Parkinson's disease: a clinical genetic analysis. Can J Neurol Sci 1995, 22:272-279.

68. Vieregge $P$, Heberlein I: Increased risk of Parkinson's disease in relatives of patients. Ann Neurol 1995, 37:685.

69. De Michele G, Filla A, Volpe G, De Marco V, Gogliettino A, Ambrosio G, Marconi R, Castellano AE, Campanella G: Environmental and genetic risk factors in Parkinson's disease: a case-control study in southern Italy. Mov Disord 1996, 11:17-23.

70. Marder K, Tang MX, Mejia H, Alfaro B, Cote L, Louis E, Groves J, Mayeux R: Risk of Parkinson's disease among first-degree relatives: A community-based study. Neurology 1996, 47:155-160.

71. Tanner CM, Ottman R, Goldman SM, Ellenberg J, Chan P, Mayeux R, Langston JW: Parkinson disease in twins: an etiologic study. JAMA 1999, 281:341-346.

72. Polymeropoulos MH, Lavedan C, Leroy E, Ide SE, Dehejia A, Dutra A, Pike B, Root H, Rubenstein J, Boyer R, Stenroos ES, Chandrasekharappa S, Athanassiadou A, Papapetropoulos T, Johnson WG, Lazzarini AM, Duvoisin RC, Di lorio G, Golbe LI, Nussbaum RL: Mutation in the alpha-synuclein gene identified in families with Parkinson's disease. Science 1997, 276:2045-2047.

73. Singleton AB, Farrer M, Johnson J, Singleton A, Hague S, Kachergus J, Hulihan M, Peuralinna T, Dutra A, Nussbaum R, Lincoln S, Crawley A, Hanson M, Maraganore D, Adler C, Cookson MR, Muenter M, Baptista M, Miller D, Blancato J, Hardy J, Gwinn-Hardy K: Alpha-Synuclein locus triplication causes Parkinson's disease. Science 2003, 302:841.

74. Kitada T, Asakawa S, Hattori N, Matsumine H, Yamamura Y, Minoshima S, Yokochi M, Mizuno Y, Shimizu N: Mutations in the parkin gene cause autosomal recessive juvenile parkinsonism. Nature 1998, 392:605-608.

75. Leroy E, Anastasopoulos D, Konitsiotis S, Lavedan C, Polymeropoulos $\mathrm{MH}$ Deletions in the Parkin gene and genetic heterogeneity in a Greek family with early onset Parkinson's disease. Hum Genet 1998, 103:424-427.

76. Valente EM, Salvi S, lalongo T, Marongiu R, Elia AE, Caputo V, Romito L, Albanese A, Dallapiccola B, Bentivoglio AR: PINK1 mutations are associated with sporadic early-onset parkinsonism. Ann Neurol 2004, 56:336-341.

77. Nichols WC, Pankratz N, Hernandez D, Paisan-Ruiz C, Jain S, Halter CA, Michaels VE, Reed T, Rudolph A, Shults CW, Singleton A, Foroud T: Genetic screening for a single common LRRK2 mutation in familial Parkinson's disease. Lancet 2005, 365:410-412.

78. Hicks AA, Petursson H, Jonsson T, Stefansson H, Johannsdottir HS, Sainz J, Frigge ML, Kong A, Gulcher JR, Stefansson K, Sveinbjornsdottir S: A susceptibility gene for late-onset idiopathic Parkinson's disease. Ann Neurol 2002, 52:549-555.

79. Pankratz N, Nichols WC, Uniacke SK, Halter C, Rudolph A, Shults C, Conneally PM, Foroud T: Significant linkage of Parkinson disease to chromosome 2q36-37. Am J Hum Genet 2003, 72:1053-1057.

80. Marx FP, Holzmann C, Strauss KM, Li L, Eberhardt O, Gerhardt E, Cookson MR, Hernandez D, Farrer MJ, Kachergus J, Engelender S, Ross CA, Berger K, Schols L, Schulz JB, Riess O, Kruger R: Identification and functional characterization of a novel R621C mutation in the synphilin-1 gene in Parkinson's disease. Hum Mol Genet 2003, 12:1223-1231.

81. Le WD, Xu P, Jankovic J, Jiang H, Appel SH, Smith RG, Vassilatis DK: Mutations in NR4A2 associated with familial Parkinson disease. Nat Genet 2003, 33:85-89.

82. Paisan-Ruiz C, Jain S, Evans EW, Gilks WP, Simon J, van der Brug M, Lopez De Munain A, Aparicio S, Gil AM, Khan N, Johnson J, Martinez JR, Nicholl D, Carrera IM, Pena AS, de Silva R, Lees A, Marti-Masso JF, Perez-Tur J, Wood NW, Singleton $A B$ : Cloning of the gene containing mutations that cause PARK8-linked Parkinson's disease. Neuron 2004, 44:595-600.

83. Lill CM, Roehr JT, McQueen MB, Kavvoura FK, Bagade S, Schjeide BM, Schjeide LM, Meissner E, Zauft U, Allen NC, Liu T, Schilling M, Anderson KJ, Beecham G, Berg D, Biernacka JM, Brice A, DeStefano AL, Do CB, Eriksson N, Factor SA, Farrer MJ, Foroud T, Gasser T, Hamza T, Hardy JA, Heutink P, Hill-Burns EM, Klein C, Latourelle JC, et al: Comprehensive research synopsis and systematic meta-analyses in Parkinson's disease genetics: The PDGene database. PLoS Genet 2012, 8:e1002548.

84. Moore DJ, West AB, Dawson VL, Dawson TM: Molecular pathophysiology of Parkinson's disease. Annu Rev Neurosci 2005, 28:57-87.

85. Lee $Y$, Dawson VL, Dawson TM: Animal models of Parkinson's disease: vertebrate genetics. Cold Spring Harb Perspect Med 2012, 2:a009324.

86. Kamp F, Exner N, Lutz AK, Wender N, Hegermann J, Brunner B, Nuscher B, Bartels T, Giese A, Beyer K, Eimer S, Winklhofer KF, Haass C: Inhibition of mitochondrial fusion by alpha-synuclein is rescued by PINK1, Parkin and DJ-1. Embo J 2010, 29:3571-3589.

87. Feany MB, Bender WW: A Drosophila model of Parkinson's disease. Nature 2000, 404:394-398.

88. Flinn L, Bretaud S, Lo C, Ingham PW, Bandmann O: Zebrafish as a new animal model for movement disorders. J Neurochem 2008, 106:1991-1997.

89. Clark IE, Dodson MW, Jiang C, Cao JH, Huh JR, Seol JH, Yoo SJ, Hay BA, Guo M: Drosophila pink1 is required for mitochondrial function and interacts genetically with parkin. Nature 2006, 441:1162-1166. 
90. da Costa CA, Ancolio K, Checler F: Wild-type but not Parkinson's disease-related ala-53 Thr mutant alpha -synuclein protects neuronal cells from apoptotic stimuli. The J biol chem 2000, 275:24065-24069.

91. Leng Y, Chuang DM: Endogenous alpha-synuclein is induced by valproic acid through histone deacetylase inhibition and participates in neuroprotection against glutamate-induced excitotoxicity. J Neurosci 2006, 26:7502-7512.

92. Yadav S, Dixit A, Agrawal S, Singh A, Srivastava G, Singh AK, Srivastava PK, Prakash O, Singh MP: Rodent models and contemporary molecular techniques: notable feats yet incomplete explanations of Parkinson's disease pathogenesis. Mol Neurobiol 2012, 46:495-512.

93. Blesa J, Phani S, Jackson-Lewis V, Przedborski S: Classic and new animal models of Parkinson's disease. J Biomed Biotechnol 2012, 2012:845618.

94. Blandini F, Armentero MT: Animal models of Parkinson's disease. Febs $J$ 2012, 279:1156-1166.

95. Langston JW, Ballard PA Jr: Parkinson's disease in a chemist working with 1-methyl-4-phenyl-1,2,5,6-tetrahydropyridine. N Engl J Med 1983, 309:310.

96. Wright JM, Wall RA, Perry TL, Paty DW: Chronic parkinsonism secondary to intranasal administration of a product of meperidine-analogue synthesis. N Engl J Med 1984, 310:325.

97. Boatell ML, Mahy N, Cardozo A, Ambrosio S, Tolosa E, Cruz-Sanchez FF: Neuronal changes in the nigrostriatal pathway of 1-methyl-4-phenylpyridine-treated mice. Methods Find Exp Clin Pharmacol 1992, 14:781-787.

98. Hoeglinger GU, Rizk P, Muriel MP, Duyckaerts C, Oertel WH, Caille I, Hirsch EC: Dopamine depletion impairs precursor cell proliferation in Parkinson disease. Nat Neurosci 2004, 7:726-735.

99. Bove J, Perier C: Neurotoxin-based models of Parkinson's disease. Neuroscience 2012, 211:51-76.

100. Shimoji M, Zhang L, Mandir AS, Dawson VL, Dawson TM: Absence of inclusion body formation in the MPTP mouse model of Parkinson's disease. Brain Res Mol Brain Res 2005, 134:103-108.

101. Ungerstedt U, Ljungberg T, Steg G: Behavioral, physiological, and neurochemical changes after 6-hydroxydopamine-induced degeneration of the nigro-striatal dopamine neurons. Adv Neurol 1974, 5:421-426.

102. Ungerstedt U, Arbuthnott GW: Quantitative recording of rotational behavior in rats after 6-hydroxy-dopamine lesions of the nigrostriatal dopamine system. Brain Res 1970, 24:485-493.

103. Manning-Bog AB, McCormack AL, Li J, Uversky VN, Fink AL, Di Monte DA: The herbicide paraquat causes up-regulation and aggregation of alpha-synuclein in mice: paraquat and alpha-synuclein. $J$ Biol Chem 2002, 277:1641-1644.

104. Betarbet R, Sherer TB, Mackenzie G, Garcia-Osuna M, Panov AV, Greenamyre JT: Chronic systemic pesticide exposure reproduces features of Parkinson's disease. Nat Neurosci 2000, 3:1301-1306.

105. Alam M, Schmidt WJ: Rotenone destroys dopaminergic neurons and induces parkinsonian symptoms in rats. Behav Brain Res 2002, 136:317-324.

106. Sherer TB, Betarbet R, Testa CM, Seo BB, Richardson JR, Kim JH, Miller GW, Yagi T, Matsuno-Yagi A, Greenamyre JT: Mechanism of toxicity in rotenone models of Parkinson's disease. J Neurosci 2003, 23:10756-10764.

107. Di Monte DA: The environment and Parkinson's disease: is the nigrostriatal system preferentially targeted by neurotoxins? Lancet Neurol 2003, 2:531-538.

108. Inden M, Kitamura Y, Takeuchi H, Yanagida T, Takata K, Kobayashi Y, Taniguchi T, Yoshimoto K, Kaneko M, Okuma Y, Taira T, Ariga H, Shimohama S: Neurodegeneration of mouse nigrostriatal dopaminergic system induced by repeated oral administration of rotenone is prevented by 4-phenylbutyrate, a chemical chaperone. J Neurochem 2007, 101:1491-1504.

109. Pan-Montojo F, Anichtchik O, Dening Y, Knels L, Pursche S, Jung R, Jackson S, Gille G, Spillantini MG, Reichmann H, Funk RH: Progression of Parkinson's disease pathology is reproduced by intragastric administration of rotenone in mice. PLoS One 2010, 5:e8762.

110. Ferrante RJ, Schulz JB, Kowall NW, Beal MF: Systemic administration of rotenone produces selective damage in the striatum and globus pallidus, but not in the substantia nigra. Brain Res 1997, 753:157-162.

111. Hoeglinger GU, Feger J, Prigent A, Michel PP, Parain K, Champy P, Ruberg M, Oertel WH, Hirsch EC: Chronic systemic complex I inhibition induces a hypokinetic multisystem degeneration in rats. J Neurochem 2003, 84:491-502.

112. Pan-Montojo F, Schwarz M, Winkler C, Arnhold M, O'Sullivan GA, Pal A, Said J, Marsico G, Verbavatz JM, Rodrigo-Angulo M, Gille G, Funk RH, Reichmann H: Environmental toxins trigger PD-like progression via increased alpha-synuclein release from enteric neurons in mice. Sci Reports 2012, 2:898.
113. Wagner J, Ryazanov S, Leonov A, Levin J, Shi S, Schmidt F, Prix C, Pan-Montojo F, Bertsch U, Mitteregger-Kretzschmar G, Geissen M, Eiden M, Leidel F, Hirschberger T, Deeg AA, Krauth JJ, Zinth W, Tavan P, Pilger J, Zweckstetter M, Frank T, Bahr M, Weishaupt JH, Uhr M, Urlaub H, Teichmann U, Samwer M, Botzel K, Groschup M, Kretzschmar H, et al: Anle138b: a novel oligomer modulator for disease-modifying therapy of neurodegenerative diseases such as prion and Parkinson's disease. Acta Neuropathologica 2013, 125:795-813.

114. Uversky VN, Li J, Fink AL: Pesticides directly accelerate the rate of alphasynuclein fibril formation: a possible factor in Parkinson's disease. FEBS Lett 2001, 500:105-108.

115. Uversky VN, Li J, Fink AL: Metal-triggered structural transformations, aggregation, and fibrillation of human alpha-synuclein. A possible molecular NK between Parkinson's disease and heavy metal exposure. J Biol Chem 2001, 276:44284-44296.

116. Chou AP, Maidment N, Klintenberg R, Casida JE, Li S, Fitzmaurice AG, Fernagut PO, Mortazavi F, Chesselet MF, Bronstein JM: Ziram causes dopaminergic cell damage by inhibiting E1 ligase of the proteasome. J Biol Chem 2008, 283:34696-34703.

117. Giordano G, Afsharinejad Z, Guizzetti M, Vitalone A, Kavanagh TJ, Costa LG: Organophosphorus insecticides chlorpyrifos and diazinon and oxidative stress in neuronal cells in a genetic model of glutathione deficiency. Toxicol Appl Pharmacol 2007, 219:181-189.

118. Schuh RA, Kristian T, Gupta RK, Flaws JA, Fiskum G: Methoxychlor inhibits brain mitochondrial respiration and increases hydrogen peroxide production and CREB phosphorylation. Toxicol Sci 2005, 88:495-504.

119. Jenkins SM, Barone S: The neurotoxicant trimethyltin induces apoptosis via caspase activation, $\mathrm{p} 38$ protein kinase, and oxidative stress in PC12 cells. Toxicol Lett 2004, 147:63-72.

120. Domico LM, Zeevalk GD, Bernard LP, Cooper KR: Acute neurotoxic effects of mancozeb and maneb in mesencephalic neuronal cultures are associated with mitochondrial dysfunction. Neurotoxicology 2006, 27:816-825.

121. Monnet-Tschudi F, Zurich MG, Pithon E, van Melle G, Honegger P: Microglial responsiveness as a sensitive marker for trimethyltin (TMT) neurotoxicity. Brain Res 1995, 690:8-14.

122. Monnet-Tschudi F, Zurich MG, Honegger P: Comparison of the developmental effects of two mercury compounds on glial cells and neurons in aggregate cultures of rat telencephalon. Brain Res 1996, 741:52-59.

123. Schapira AH, Cooper JM, Dexter D, Jenner P, Clark JB, Marsden CD: Mitochondrial complex I deficiency in Parkinson's disease. Lancet 1989, 1:1269.

124. Parker WD Jr, Boyson SJ, Parks JK: Abnormalities of the electron transport chain in idiopathic Parkinson's disease. Ann Neurol 1989, 26:719-723.

125. Haas RH, Nasirian F, Nakano K, Ward D, Pay M, Hill R, Shults CW: Low platelet mitochondrial complex I and complex II/III activity in early untreated Parkinson's disease. Ann Neurol 1995, 37:714-722.

126. Rybakowska I, Szreder G, Kaletha K, Barwina M, Waldman W, Sein Anand J: [Reactive oxygen species and 3,4-dihydroxyphenylacetaldehyde in pathogenesis of Parkinson disease]. Przegl Lek 2011, 68:486-487.

127. Lee J, Giordano S, Zhang J: Autophagy, mitochondria and oxidative stress: cross-talk and redox signalling. Biochem J 2012, 441:523-540.

128. Li JY, Englund E, Holton JL, Soulet D, Hagell P, Lees AJ, Lashley T, Quinn NP, Rehncrona S, Bjorklund A, Widner H, Revesz T, Lindvall O, Brundin P: Lewy bodies in grafted neurons in subjects with Parkinson's disease suggest host-to-graft disease propagation. Nat Med 2008, 14:501-503.

129. Brundin P, Li JY, Holton JL, Lindvall O, Revesz T: Research in motion: the enigma of Parkinson's disease pathology spread. Nat Rev Neurosci 2008, 9:741-745.

130. Desplats P, Lee HJ, Bae EJ, Patrick C, Rockenstein E, Crews L, Spencer B, Masliah E, Lee $S J$ : Inclusion formation and neuronal cell death through neuron-to-neuron transmission of alpha-synuclein. Proc Natl Acad Sci U S A 2009, 106:13010-13015.

131. Alvarez-Erviti L, Seow Y, Schapira AH, Gardiner C, Sargent IL, Wood MJ, Cooper JM: Lysosomal dysfunction increases exosome-mediated alpha-synuclein release and transmission. Neurobiol Dis 2011, 42:360-367.

132. McGeer PL, Itagaki S, Boyes BE, McGeer EG: Reactive microglia are positive for HLA-DR in the substantia nigra of Parkinson's and Alzheimer's disease brains. Neurology 1988, 38:1285-1291.

133. McGeer PL, McGeer EG: Inflammation and neurodegeneration in Parkinson's disease. Parkinsonism Relat Disord 2004, 10(Suppl 1):S3-S7. 
134. Boka G, Anglade P, Wallach D, Javoy-Agid F, Agid Y, Hirsch EC: Immunocytochemical analysis of tumor necrosis factor and its receptors in Parkinson's disease. Neurosci Lett 1994, 172:151-154.

135. Hunot S, Hirsch EC: Neuroinflammatory processes in Parkinson's disease. Ann Neurol 2003, 53(Suppl 3):S49-S58. discussion S58-60.

136. Gao HM, Hong JS, Zhang W, Liu B: Synergistic dopaminergic neurotoxicity of the pesticide rotenone and inflammogen lipopolysaccharide: relevance to the etiology of Parkinson's disease. J Neurosci 2003, 23:1228-1236.

137. Kohbata S, Beaman BL: L-dopa-responsive movement disorder caused by Nocardia asteroides localized in the brains of mice. Infect Immun 1991 59:181-191

138. Gao HM, Jiang J, Wilson B, Zhang W, Hong JS, Liu B: Microglial activation-mediated delayed and progressive degeneration of rat nigral dopaminergic neurons: relevance to Parkinson's disease. J Neurochem 2002, 81:1285-1297.

139. Dutta G, Zhang P, Liu B: The lipopolysaccharide Parkinson's disease animal model: mechanistic studies and drug discovery. Fundam Clin Pharmacol 2008, 22:453-464.

140. Hunot S, Dugas N, Faucheux B, Hartmann A, Tardieu M, Debre P, Agid Y, Dugas B, Hirsch EC: FcepsilonRII/CD23 is expressed in Parkinson's disease and induces, in vitro, production of nitric oxide and tumor necrosis factor-alpha in glial cells. J Neurosci 1999, 19:3440-3447.

141. Wong CH, Crack PJ: Modulation of neuro-inflammation and vascular response by oxidative stress following cerebral ischemia-reperfusion injury. Curr Med Chem 2008, 15:1-14.

142. McGeer PL, McGeer EG: The alpha-synuclein burden hypothesis of Parkinson disease and its relationship to Alzheimer disease. Exp Neurol 2008, 212:235-238.

143. Gao HM, Zhang F, Zhou H, Kam W, Wilson B, Hong JS: Neuroinflammation and alpha-synuclein dysfunction potentiate each other, driving chronic progression of neurodegeneration in a mouse model of Parkinson's disease. Environ Health Perspect 2011, 119:807-814.

144. Esteves AR, Arduino DM, Silva DF, Oliveira CR, Cardoso SM: Mitochondrial dysfunction: The road to alpha-synuclein oligomerization in PD. Parkinsons Dis 2011, 2011:693761.

145. Freeman D, Cedillos R, Choyke S, Lukic Z, McGuire K, Marvin S, Burrage AM, Sudholt S, Rana A, O'Connor C, Wiethoff CM, Campbell EM: Alpha-synuclein induces lysosomal rupture and cathepsin dependent reactive oxygen species following endocytosis. PLoS One 2013, 8:e62143.

146. Chinta SJ, Mallajosyula JK, Rane A, Andersen JK: Mitochondrial alpha-synuclein accumulation impairs complex I function in dopaminergic neurons and results in increased mitophagy in vivo. Neurosci Lett 2010, 486:235-239.

147. Braidy N, Gai WP, Xu YH, Sachdev P, Guillemin GJ, Jiang XM, Ballard JW, Horan MP, Fang ZM, Chong BH, Chan DK: Alpha-synuclein transmission and mitochondrial toxicity in primary human foetal enteric neurons in vitro. Neurotox Res 2014, 25:170-182.

148. Klegeris A, Giasson Bl, Zhang H, Maguire J, Pelech S, McGeer PL: Alpha-synuclein and its disease-causing mutants induce ICAM- 1 and IL- 6 in human astrocytes and astrocytoma cells. FASEB J 2006, 20:2000-2008.

149. Gao HM, Kotzbauer PT, Uryu K, Leight S, Trojanowski JQ, Lee VM: Neuroinflammation and oxidation/nitration of alpha-synuclein linked to dopaminergic neurodegeneration. J Neurosci 2008, 28:7687-7698.

150. Frank-Cannon TC, Tran T, Ruhn KA, Martinez TN, Hong J, Marvin M, Hartley M, Trevino I, O'Brien DE, Casey B, Goldberg MS, Tansey MG: Parkin deficiency increases vulnerability to inflammation-related nigral degeneration. J Neurosci 2008, 28:10825-10834.

151. Norris EH, Uryu K, Leight S, Giasson BI, Trojanowski JQ, Lee VM: Pesticide exposure exacerbates alpha-synucleinopathy in an A53T transgenic mouse model. Am J Pathol 2007, 170:658-666.

152. Manning-Bog AB, McCormack AL, Purisai MG, Bolin LM, Di Monte DA: Alpha-synuclein overexpression protects against paraquat-induced neurodegeneration. J Neurosci 2003, 23:3095-3099.

153. Kahle PJ, Waak J, Gasser T: DJ-1 and prevention of oxidative stress in Parkinson's disease and other age-related disorders. Free Radic Biol Med 2009, 47:1354-1361.

154. Masliah E, Dumaop W, Galasko D, Desplats P: Distinctive patterns of DNA methylation associated with Parkinson disease: identification of concordant epigenetic changes in brain and peripheral blood leukocytes. Epigenetics 2013, 8:1030-1038.
155. lacobazzi V, Castegna A, Infantino V, Andria G: Mitochondrial DNA methylation as a next-generation biomarker and diagnostic tool. Mol Genet Metab 2013, 110:25-34

156. Marques S, Outeiro TF: Epigenetics in Parkinson's and Alzheimer's diseases. Sub-cellular biochemistry 2013, 61:507-525.

157. Harrison IF, Dexter DT: Epigenetic targeting of histone deacetylase: therapeutic potential in Parkinson's disease? Pharmacol Ther 2013, 140:34-52.

158. Nussbaum JM, Schilling S, Cynis H, Silva A, Swanson E, Wangsanut T, Tayler K, Wiltgen B, Hatami A, Ronicke R, Reymann K, Hutter-Paier B, Alexandru A, Jagla W, Graubner S, Glabe CG, Demuth HU, Bloom GS: Prion-like behaviour and tau-dependent cytotoxicity of pyroglutamylated amyloid-beta. Nature 2012, 485:651-655

doi:10.1186/2047-9158-3-10

Cite this article as: Pan-Montojo and Reichmann: Considerations on the role of environmental toxins in idiopathic Parkinson's disease pathophysiology. Translational Neurodegeneration 2014 3:10.

\section{Submit your next manuscript to BioMed Central and take full advantage of:}

- Convenient online submission

- Thorough peer review

- No space constraints or color figure charges

- Immediate publication on acceptance

- Inclusion in PubMed, CAS, Scopus and Google Scholar

- Research which is freely available for redistribution

Submit your manuscript at www.biomedcentral.com/submit
C BioMed Central 